\title{
Inferring Peer-Related Emotions in a Collaborative Learning Game
}

\author{
Edilson Pontarolo, UTFPR, Brazil, epontarolo@utfpr.edu.br \\ Rosa Maria Vicari, UFRGS, Brazil, rosa@inf.ufrgs.br \\ Patrícia Augustin Jaques, UNISINOS, Brazil, pjaques@unisinos.br \\ Sylvie Pesty, INP Grenoble, France, sylvie.pesty@imag.fr
}

\begin{abstract}
This paper presents an affective model to infer student's emotions in a collaborative learning game. The model is focused on the representation and recognition of emotions closer to the collaboration dynamics (e.g., pride, shame, admiration and reproach). Consistently to a cognitive approach, the student's emotions are represented and inferred by modeling the student's cognitive appraisal of interactions praiseworthiness, evaluated according to her/his standards. The affective student model relies on Bayesian Networks, through which the causal dependencies among student's personality traits, goals, behavioral standards, interactions and emotions are mapped. A collaborative testbed game that provides simple interaction mechanisms was implemented. Using the testbed game, students can construct shared solutions of a class of logical problems. The cognitive and affective variables of the model and their probabilistic relationships are detailed and the capture of interaction evidence from the testbed game is discussed.
\end{abstract}

Keywords: affective student modeling, pedagogical games, computer-supported collaborative learning

\section{Resumo}

Este artigo apresenta um modelo afetivo para inferir emoções do aluno em um jogo de aprendizagem colaborativa. O modelo é focado na representação e reconhecimento de emoções vinculadas a uma dinâmica de colaboração (tais como orgulho, vergonha, admiração e reprovação). O modelo emprega uma abordagem cognitiva em que as emoções do aluno são representadas e inferidas pela representação da avaliação cognitiva que o aluno faz sobre a "louvabilidade" das interações colaborativas durante o jogo, de acordo com suas expectativas de padrões comportamentais. O modelo afetivo do aluno se apóia em Redes Bayesianas, através das quais são mapeadas dependências causais entre traços da personalidade, objetivos, padrões comportamentais, interações e emoções do aluno. Um jogo colaborativo que suporta mecanismos simples de interação foi implementado como protótipo de teste. Ao fazer uso deste jogo, alunos podem construir soluções compartilhadas de uma classe de problemas lógicos. As variáveis afetivas e cognitivas do modelo e suas relações probabilísticas são detalhadas e a captura de evidências da interação a partir do jogo protótipo é discutida.

Palavras-chave: modelagem afetiva do aluno, jogos pedagógicos, aprendizagem colaborativa apoiada por computador 


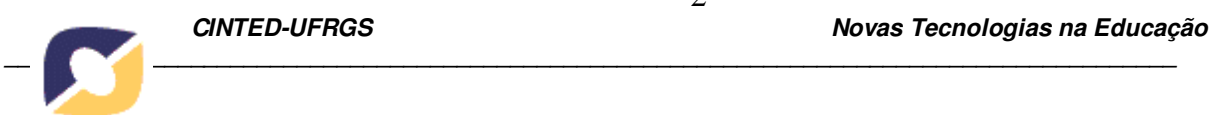

\section{Introduction}

Both theoretical and empirical neuropsychology and related research have suggested the influence of human affective states on the capacity of accomplishing cognitive tasks. Particularly, it has been highlighted the emotions' potential for positive (or negative) impact on attention, learning and problem solving (Damasio, 1994; Estrada et al., 1994; Izard et al., 1984). In the context of Computer in Education, these findings point to the necessity of addressing the problem of Affective User Modeling, defined by Elliot et al. (1999) as the capacity of the computational system to model the user's affective states. The capacity of recognizing student's emotions can be viewed as a basic step in order to improve the believability of educational systems, as in the case of lifelike pedagogical agents (Jaques et al., 2003; Lester and Stone, 1997), fostering the student's motivation and commitment during learning activities. The design and implementation of digital learning games (also called edutainment or pedagogical games) has been addressed by some authors (Barab et al., 2005; Virvou and Katsionis, 2008), notably paying attention to the digital games' capacity of keeping users' attention and motivation (Dempsey et al., 1996; Prensky, 2001).

The rest of this paper is organized as follows. In section 2, some related works are discussed. In section 3, a collaborative game is described as a platform to study student's peer-related emotions. In section 4, the affective student model is presented. It is discussed how to capture and organize data from students' interaction dynamics in order to infer their emotions towards their peers during collaboration. In section 5, some concluding remarks are discussed.

\section{Related work}

There are other works in Computer in Education research area also interested in inferring student's emotions following a cognitive approach (Elliot et al., 1999), including learning games (Conati, 2002; Katsionis and Virvou, 2004; Martinho et al., 2000).

A first work that proposed the integration of cognitive-based affective modeling in pedagogical agents is Elliot and colleagues' one (Elliot et al., 1999). The paper discusses how to integrate the Affective Reasoner, based on the OCC theory (Ortony et al., 1988), in Herman agent (Lester and Stone, 1997) in order to infer and model student's emotions. However, the article does not show how to identify the student's goals in order to infer his/her emotions. The authors assume that the user's goals and preferences necessary to define the outcome of the appraisal are known.

Martinho et al. (2000) proposed an affective user model for the collaborative game Teatrix. In Teatrix children collaborate with each other to create a story. Each child controls a character by selecting actions from a list of available actions. The affective model is divided in two parts: (1) the user emotional profile contains information about the "resistance" that the user experiences an emotion and how long the user feels it; and (2) the emotions that the user experiences. Like in the proposed work, the emotions are inferred by the observable behavior of the student (actions in the 
game) according to the OCC model. Nevertheless, the model was described generically, as a framework.

Conati (2002) described a probabilistic model for student's emotions inference in an educational computer game that considers 6 emotions (joy, distress, pride, shame, admiration and reproach), also based on OCC psychological model (Ortony et al., 1988). To determine student's possible goals, a questionnaire was filled by students and they were observed playing the game. The goals are inferred by student's personality and by how the students play the game (for example, students that have the goal "have fun" are more likely to move quickly). This proposal differs from Conati's work because it considers emotions that students feel towards their game peers in collaborative games. Although Conati's model was also applied in a collaborative game, it just considers emotions that arise from the evaluation of event's desirability according to one's goals or emotions that the students experience towards the animated pedagogical agent. As long as we know, the problem of recognizing users' emotions towards their game peers has not been addressed.

\section{Collaborative learning games}

In this project, a game is an intentionally organized set of rule-guided dynamic activities, presenting goals, constraints, payoffs, consequences and a degree of competition (Dempsey et al., 1996). In a multiplayer game, two or more players interact through a combination of collaboration and competition processes, depending on the objectives focused by the game project. A carefully planed combination of these dynamics justifies the application of games as suitable environments for Computer-Supported Collaborative Learning (Dillenbourg, 1999; Manninen, 2002). In projecting a learning game, it is important to track the goal of providing an environment for learning while playing, instead of playing (just) for learning. Otherwise one risks of losing the intrinsic motivational appeal that makes games an interesting pedagogical resource.

This research focuses games that support learning through collaboration into small scale groups. Indeed, the proposed affective model (see Section 4) considers the peer-to-peer scope of collaborative couples, by mapping the student's emotions concerning a collaboration partner. A collaborative game is thus loosely characterized as a game-type situation in which two people learn how to solve a problem together (Dillenbourg, 1999), respecting additionally: (1) a symmetry in the interaction between peers, with respect to the available resources; (2) the presence of shared goals (although individual goals are possible); and (3) a mutual commitment of the peers to coordinate their efforts in order to solve the problem jointly. Given these constraints, in this project, two students are engaged in distant synchronous interaction, combining mutual efforts on the solution of reasoning shared problems, supported by a game server.

\subsection{The testbed game}

A game called The Collaborative Sudoku was implemented, regarding the recent popularization of this class of logical puzzles. In its most popular version, a Sudoku (nearly "single number", in Japanese) is a logic-based number placement puzzle. The objective is to fill a $9 \times 9$ grid so that each column, each row, and each of the nine $3 \times 3$ 
regions (sub-grids) contain the digits from 1 to 9 , only one time each. The size and disposition of the initial setting define the difficulty level associated to the solution of each specific Sudoku. Despite the fact that its generalized logical solution characterizes an NP-complete problem (Lewis, 2007), the standalone solution of most Sudoku problems requires relatively simple spatial reasoning, visualization and experimentation. This work is interested in what happens in terms of peer-related emotions when such a "simple" logical task is addressed collaboratively.

By means of the web-based interface shown in Figure 1, each player logs-in the game server and invites (or is invited by) another logged-in player in order to form a couple. The game server synchronizes matches between pairs of couples, working separately on the same sequence of Sudoku problems. A couple does not interfere directly on its adversaries' solution. A match is completed when a couple fulfils the grid with the expected solution and has no more cells waiting for negotiation. Under this condition, the game server warns both involved couples and starts a new problem to be solved. Two progress bars shows comparatively the synchronous evolution of the different solutions under construction by the two matching couples. The partners collaborate through negotiation and communication, while trying to find the solution faster than their adversaries. This combination of collaboration and semi-direct competition dynamics is intended to foster the users' engagement with the task, while the affective focus is kept upon the game partner.

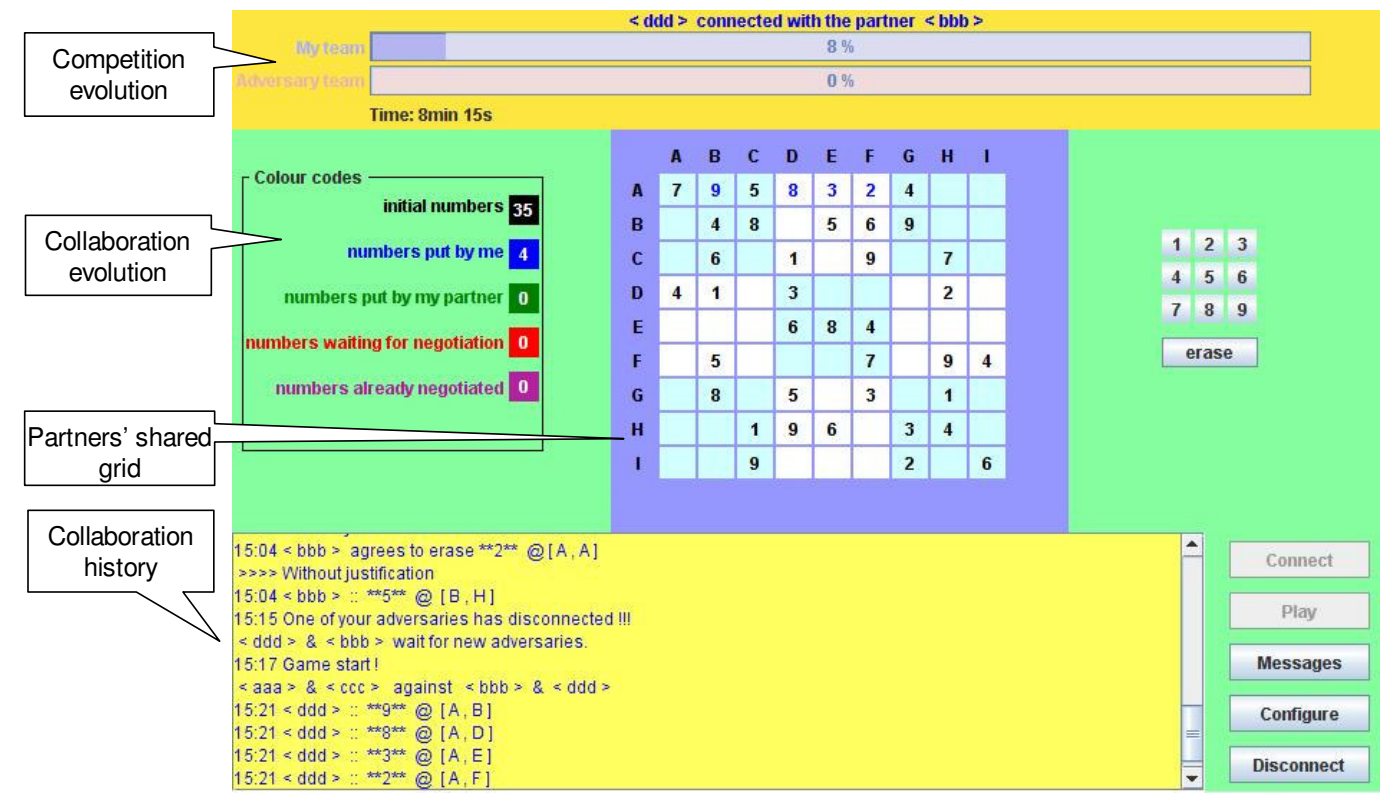

Figure 1 - The Collaborative Sudoku interface

The game does not control playing turns, thus the empty cells are filled by the partner that firstly attempts to do so, i.e., although synchronous, the game is not modal. Once a cell holds a digit, its replacement or erasing is possible only through negotiation, regardless which of the partners has placed it. A color scheme is made available to keep the users' visual awareness of cells status. A cell under negotiation keeps locked for the player that made the last proposition on it, being addressable by a new negotiation cycle. 


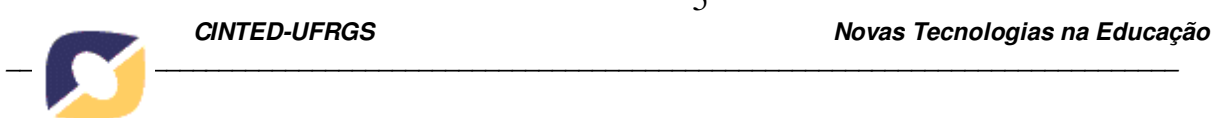

A typed justification may be added to negotiation propositions and responses. In order to keep fluidity in game-playing and simplicity in monitoring, the partners may exchange text structured messages. The current set includes predefined messages of greeting, complaining, congratulation, helping, and performance highlighting types.

\section{The affective student model}

The proposed affective model employs a cognitive approach. Information from the partners' interaction (coordination, negotiation and communication) is captured during collaboration, and the model represents the emotions as reactions resulting from the student's cognitive appraisal of a situation. Here, a situation is "the consequence of an action" performed by the student or by her/his collaboration partner.

The inference of emotions is based on Ortony, Clore and Collins (OCC) psychological model of emotions (Ortony et al., 1988), and thus the proposed model considers the partners' actions as a source of situational information to infer 4 peer-related emotions: admiration or reproach, and pride or shame (i.e., the group of "attribution" emotions in the OCC model). The partners' actions are evaluated in terms of their praiseworthiness, i.e., how much they are coherent with the student's standards. In the OCC model, standards are prototypical models of behavior, performance and moral. In the proposed work, only behavioral standards are considered, through variables representing the student's norms in terms of goals-related behaviors.

The chosen modeling technique relies on Bayesian Networks (BN) (Jensen, 2001; Pearl, 1988), through which some conceptually derived causal dependencies among students' personality traits, goals, behavioral standards, interactions and emotions are mapped. In fact, the proposed model represents its beliefs about these student's cognitive and affective uncertain data through random variables, related by Conditional Probability Tables (CPTs). Additionally, such knowledge representation facilitates model visualization and is suitable to be refined through controlled experiments.

An overview of the proposed model is shown in Figure 2. The student's Goals and Standards are considered to have a causal dependency of the student's Personality Traits. This part of the model is based on Goldberg's Big-Five Model of Personality Traits (Goldberg, 1990). Student's Interactions are considered to have a causal dependency of the student's stronger (or weaker) commitment with certain goals than with others. In a collaborative game, the student's own actions as well as her/his partner's actions produce the observable outcomes in the game dynamics. The peer-related Emotions take place as the student observes these outcomes as consequences of the related actions, and evaluate them according to his/her Standards. 


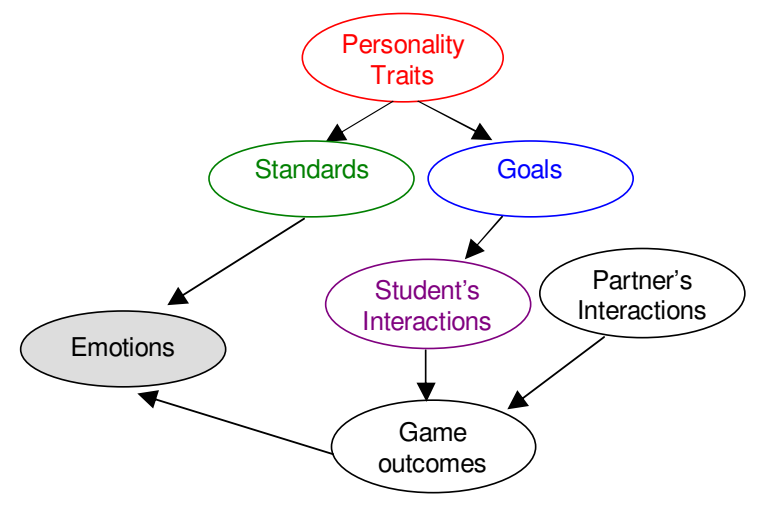

Figure 2 - Classes of bayesian variables and dependencies in the affective model

The model's upper part is employed to infer the student's goals and standards. Evidence from student's interaction is captured from the game and allows the inference of her/his goals, and consequently, through the CPTs, of her/his personality and behavioral standards. A more detailed representation of these variables and some conceptually supposed relations are shown in Figure 3.

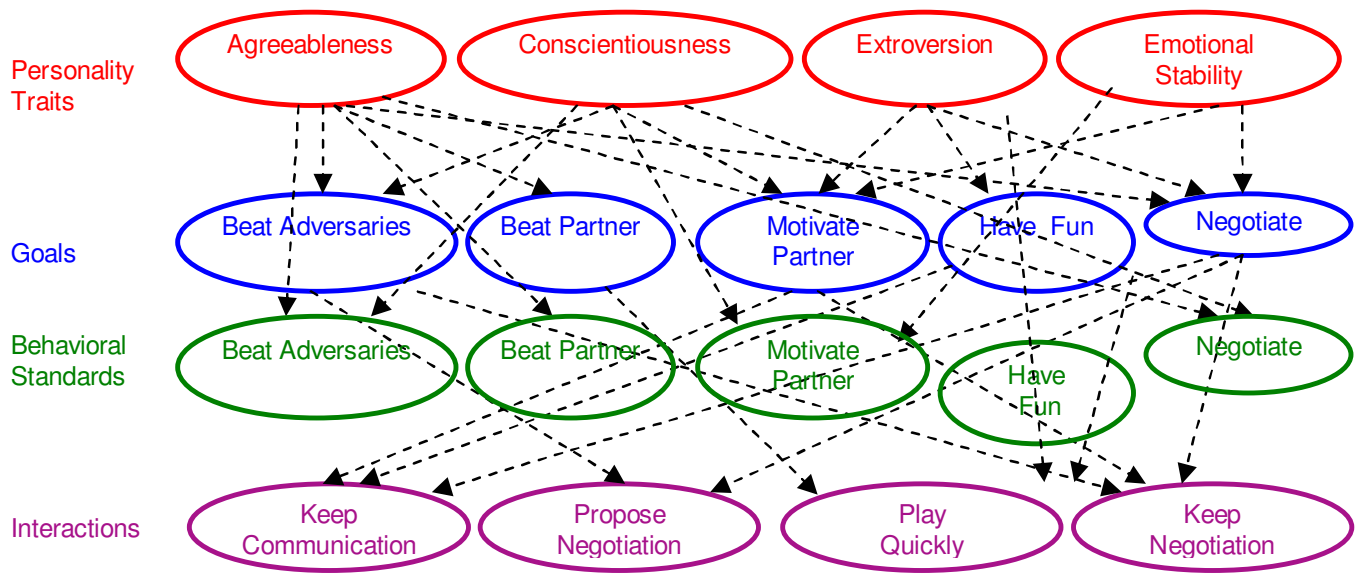

Figure 3 - Variables and dependencies employed to infer student's goals and standards

Figure 4 shows the peer-related emotions of admiration or reproach, and pride or shame, inferred as the student approves or disapproves the partners' actions, according to her/his standards. The partner's actions that generate most significant consequences, i.e., game outcomes that give rise to admiration or reproach, from the student's point-ofview follow: (1) Propose: the partner sends a justified (or an unjustified) proposition. (2) Agree: the partner sends an "agree" (or disagree) to a proposition. (3) Nothing: the partner spends long time "doing nothing". (4) Message: the partner sends a "positive" (or negative) message. (5) Overcome: the partner makes a movement that overcomes (or is overcome by) the student's contribution. (6) Improve: the partner makes a movement that improves (or worsens) the solution relatively to the adversaries' one. The game outcomes are equivalently defined for the student's evaluation of his/her own actions, given rise to pride or shame emotions. The affective model evaluates the situation according to the same set of behavioral standards and two different sets of 


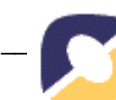

game outcomes, one for the user's actions and another for the partner's ones (not duplicated in Figure 4 to keep clarity).

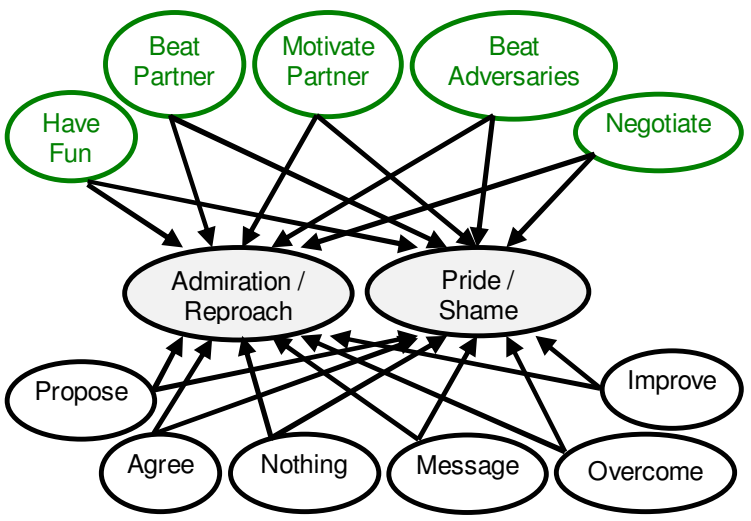

Figure 4 - Student's peer-related emotions

\section{Concluding remarks}

This paper presented an affective model to represent and infer the students' emotions in a collaborative game. The model follows a cognitive approach, i.e. it recognizes students' emotions by inferring their appraisal of the partners' actions consequences. More specifically, the proposed model is conceptually based on the OCC theory in order to infer 4 emotions: pride or shame, and admiration or reproach. The Big-Five psychological model of personality traits provides the indices of behavioral standards, employed by students for appraisal of their own and colleagues' actions.

The knowledge representation is based on BN technology and the qualitative and quantitative refinement and evaluation is data-driven. These data will be obtained by means of controlled experiments. First, a calibration experiment will be performed in order to build a case base, with which the model will be submitted to a refinement. The qualitative refinement can determine new variables and relations to be added in the affective model or it can show variables or relations that could be removed from the initial model (presented in Section 4). Second, the quantitative refinement will permit to determine the probabilistic relations among the model variables that are connected, through CPTs. Once the model was refined, a validation experiment will be employed in order to verify the model accuracy. Both evaluations will be made with computer science undergraduate students. In order to assess the students' current emotions, it will be used dialog boxes as shown in Figure 5. During the calibration experiment the dialog boxes appear in each 3 minutes. During the verification experiment they will appear in each 5 minutes and also each time that the system infers an emotion. 


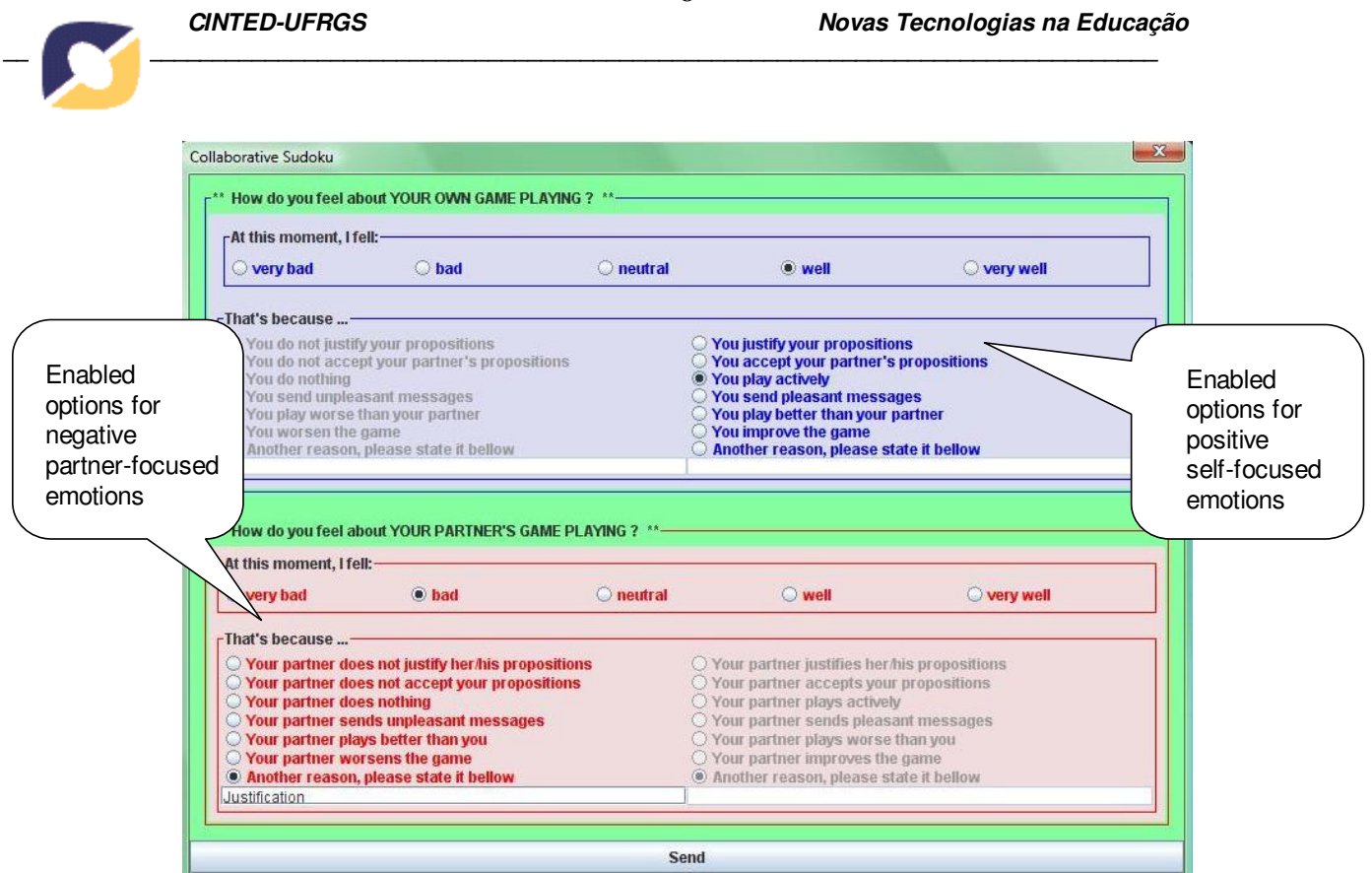

Figure 5 - The dialog box for affective state self-report

Although it is not an ideal solution, early studies (Conati, 2004) showed that this option is less intrusive than asking the students to describe their emotions during the game interaction, which can interfere in the emotional states that the model tries to infer. Besides, it is not feasible to ask the students to describe them after the game, since, as the game takes long time to be solved, maybe the students will not remember any more their emotions. It is also important that the dialog boxes appear automatically, since previous experiments (Conati and McLaren, 2004) showed that students forget to access voluntarily the dialog boxes to report their emotional states.

The personality traits data are collected by employing on-line adapted versions ${ }^{1}$ of the freely available Big-Five inventory (Goldberg, 1999) and a scoring procedure based on local norms. The goals and behavioral standards are collected by employing an on-line questionnaire ${ }^{2}$, applied just after the experimental game playing session, so the students still can evaluate their commitment with the different goals and their expectations during the game. In both questionnaires, a Likert five points scale ("strongly disagree", "disagree", "neutral", "agree", "strongly agree") is associated to each question.

\section{Notes}

${ }^{1}$ The personality inventories are available at http://gia.inf.ufrgs.br/collab/aces.

${ }^{2}$ The goals and standards inventories are available at http://gia.inf.ufrgs.br/collab/buts.

\section{Acknowledgements}




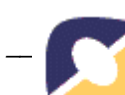

This work is partially granted by Brazilian and French research agencies: CNPq Brazil grant 507308/2004-2, and the first author's CAPES PhD stage scholarship, by means of the cooperation project between CAPES Brazil / COFECUB France.

\section{References}

BARAB, S.; THOMAS, M.; DODGE, T.; CARTEAUX, R.; TUZUN, H. Making Learning Fun: Quest Atlantis, A Game Without Guns. Educational Technology Research and Development, v.53, n.1, p.86-107, 2005.

CONATI, C. How to evaluate models of user affect?. In: TUTORIAL AND RESEARCH WORKSHOP ON AFFECTIVE DIALOGUE SYSTEMS, Kloster Irsee: 2004, p.288-300.

CONATI, C. Probabilistic Assessment of User's Emotions in Educational Games. Journal of Applied Artificial Intelligence, v.16, n.7-8, 2002.

CONATI, C.; MCLAREN, H. Evaluating a Probabilistic Model of Student Affect. In: INTERNATIONAL CONFERENCE ON INTELLIGENT TUTORING SYSTEMS, 7., 2004, Maceió, Brazil. Heidelberg: Springer, 2004, p.55-66.

DAMASIO, A. Descartes' Error: Emotion, Reason, and the Human Brain. New York: Avon Books, 1994.

DEMPSEY, J.V.; LUCASSEN, B.A.; HAYNES, L.L.; CASEY, M.S. Instructional Applications of Computer Games. In: ANNUAL MEETING OF THE AMERICAN EDUCATIONAL RESEARCH ASSOCIATION, 1996. New York: American Educational Research Association, 1996.

DILLENBOURG, P. What do you mean by collaborative learning?. In: DILlENBOURG, P. (Ed.), Collaborative Learning: Cognitive and Computational Approaches. Amsterdan: Elsevier Science, 1999. p.1-19.

ELLIOTT, C.; BRZEZINSKI, J. Autonomous Agents as Synthetic Characters. AI Magazine, v.19, p.13-30, 1998.

ELLIOT, C.; RICKEL, J.; LESTER, J.C. Lifelike Pedagogical Agents and Affective Computing: An Exploratory Synthesis. In: Artificial Intelligence Today. WOOLDRIDGE, M.; VELOSO, M.M. (Eds.), Berlin: Springer, 1999. p.195-212.

ESTRADA, C.; ISEN, A.; YOUNG, M. Positive affect influences on creative problem solving reported source of practice satisfaction in physicians. Motivation and Emotion, v.18, p.285-299, 1994. 


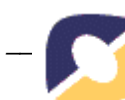

GOLDBERG, L. R. A Broad-Bandwidth, Public-Domain, Personality Inventory Measuring the Lower-Level Facets of Several Five-Factor Models. In: Personality Psychology in Europe, Tilburg: Tilburg University Press, 1999. p. 7-28.

GOLDBERG, L. R. An alternative "description of personality": The Big-Five factor structure. Journal of Personality and Social Psychology, Washington DC, v.59, p.1216-1229, 1990.

IZARD, C.; KAGAN, J.; ZAJONC, R.B. (Eds.). Emotions, cognition, and behavior. New York: Cambridge University Press, 1984.

JAQUES, P.; VICCARI, R.; PESTY, S. An Animated Pedagogical Agent that Interacts Affectively with the Student. In: INTERNATIONAL CONF. OF ARTIFICIAL INTELLIGENCE IN EDUCATION, 11., 2003, Sydney, Australia: IOS Press, 2003.

JENSEN, F. Bayesian networks and decision graphs. New York: Springer, 2001.

KATSIONIS, G.; VIRVOU, M. A cognitive theory for affective user modelling in a virtual reality educational game. In: IEEE INTERNATIONAL CONF. SYSTEMS, MAN AND CYBERNETICS, 17., 2004. Piscataway, NJ: IEEE, 2004, p.1209-1213.

LESTER, J.; STONE, B. Increasing Believability in Animated Pedagogical Agents. In: INTERNATIONAL CONFERENCE ON AUTONOMOUS AGENTS, 1., 1997, Marina del Rey, CA, USA, 1997, p.16-21.

LEWIS, R. Metaheuristics can solve sudoku puzzles. Journal of Heuristics, v.13, n.4, p.387-401, 2007.

MANNINEN, T. Towards Communicative, Collaborative and Constructive Multiplayer Games. In: COMPUTER GAMES AND DIGITAL CULTURES CONFERENCE, 2002, Tampere, Finland. Tampere, Finland: Tampere University Press, 2002. p.155-169.

MARTINHO, C.; MACHADO, I.; PAIVA, A. A Cognitive Approach to Affective User Modeling. In: Affective Interactions, LNCS 1814, Berlin: Springer, 2000. p.64-75.

ORTONY, A.; CLORE, G.; COLLINS, A. The cognitive structure of emotions. Cambridge, UK: Cambridge Press, 1988.

PEARL, J. Probabilistic Reasoning in Intelligent Systems. San Mateo, CA, USA: Morgan Kaufmann, 1988.

PRENSKY, M. Digital game-based learning. New York: McGraw-Hill, 2001.

VIRVOU, M.; KATIONIS, G. On the usability and likeability of virtual reality games for education: The case of VR-ENGAGE. Computers \& Education, Oxford, UK, v.50, n.1, p.154-178, 2008. 